\title{
Evaluation of the Utilization of Tax Incentive Policies during the Covid-19 Pandemic in the Framework of National Economic Recovery
}

\author{
Ratih Kumala ${ }^{1}$, Ibrahim Abu Bakar ${ }^{2}$ \\ ${ }^{1}$ Institut Ilmu Sosial dan Manajemen STIAMI, Indonesia \\ ${ }^{2}$ Abubakar Tatari Ali Polytechnic, Nigeria \\ Correspondent: rhaty07@gmail.com ${ }^{1}$
}

\begin{tabular}{ll}
\hline Received & : August 26, 2021 \\
Accepted & : January 15, 2022 \\
Published & : January 31, 2022
\end{tabular}

Citation: Kumala, R., Bakar, I, A (2022). Evaluation of the Utilization of Tax Incentive Policies during the Covid-19 Pandemic in the Framework of National Economic Recovery. Ilomata International Journal of Tax \& Accounting.3(1), 13-21.

https://doi.org/10.52728/ijtc.v4i1.422

\begin{abstract}
Until now, Indonesia still faces Covid-19 and is still in the process of economic recovery. However, the Directorate General of Taxes (DGT) was able to achieve the target of $100 \%$ tax revenue according to the target mandated in the 2021 State Budget even before the close of the year. At the end of 2021 tax incentives that have been utilized in the framework of the National Economic Recovery Program have reached IDR 63.16 trillion (100.5\%) from the ceiling of IDR 62.83 trillion. This achievement is thanks to the contributions of all Taxpayers who continue to be committed to paying taxes. On this achievement, the government continues to show improvement efforts that must be maintained momentum, in order to continue to the 2022 state budget. The purpose of this study is to find out and analyze the evaluation of the utilization of tax incentive policies during the covid-19 pandemic in the framework of national economic recovery. This research uses descriptive qualitative methods through literature studies. In the evaluation of the utilization of tax incentive policies during the Covid-19 pandemic, it was explained that this tax revenue is one of the many state revenues that participate in supporting the nation and the country.
\end{abstract}

Keywords: Covid-19, tax incemtive, recovery.

(c) This is an open access article under the
CC-BY 4.0 license.

\section{INTRODUCTION}

Currently almost all countries in the world are experiencing the Covid-19 pandemic. This pandemic has a very bad impact on the countries that experience it, because it not only harms health but also affects the economic side of countries around the world, not least Indonesia (Resmi \& Barmawi, 2022). Like other developing countries, Indonesia is particularly vulnerable to the Covid-19 pandemic (Barbier \& Burgess, 2020). Indonesia was less responsive in the early days of Covid-19 (Fadhal, 2020). While many countries in Asia and Western Europe have tightened the flow of people in and out to prevent Covid-19, Indonesia had not yet implemented significant policies by continuing to enforce normal human inflows from abroad (Sparrow et al., 2020).

To prevent the spread of the Covid-19 outbreak, policies are needed by implementing health protocols in the form of physical distancing and social restrictions because there is a link between Covid-19 control efforts and economic impacts (Baldwin \& Tomiura, 2020). This policy choice 


\section{Evaluation of the Utilization of Tax Incentive Policies during the Covid-19 Pandemic in the Framework of National Economic Recovery \\ Kumala and Bakar}

carries significant consequences of reducing community and business activity. Output then came under pressure, prompting the economy to continue slowing into recession (Malahayati et al., 2021). To prevent a deeper recession, the Government needs to issue stimulus policies (Wiryawan, 2020). Policy priority is given to mitigate the negative impact on vulnerable community groups and the business world so as not to lead to bankruptcy. Stimulus policies are also carried out so that the decline in welfare felt by the community does not have a negative impact outside the economy, such as social and political turmoil (Muhyiddin \& Nugroho, 2020).

For that, President Joko Widodo asked some parties for the enactment of the lockdown of course has an impact on the government economic sector (Anderson et al., 2020). These pandemics have become a significant threat to human physical, mental health and dramatically affected daily life with psychosocial implications on a global scale (Kurniawan, 2021). The impact of the Covid-19 pandemic on public health is completely beyond everyone's imagination (Kurniawan, 2021). Pandemics have hit more than 210 countries, and most of these countries are still under a variety of infection control measures, including lockdown, quarantine, mandatory use of mask, and public distance (Wang et al., 2021).

The highest state revenue comes from tax revenues. The government is still trying to achieve tax revenue targets by revising tax incentives by 2020. The government needs state revenue through taxes to help in handling the covid-19 outbreak and on the other hand the government also wants to relieve people who are experiencing economic difficulty due to this outbreak (Sariwati, 2021; Wantasen et al., 2021).

To mitigate these negative impacts, governments can implement economic policy packages such as fiscal, monetary, and financial (Gourinchas, 2020). One of the government's efforts in the field of taxation in the national economic recovery is the existence of tax incentive policies. This tax incentive policy aims to help move the wheels of the country's economy which is experiencing rapid decline due to the Covid-19 pandemic (Andrew \& Sari, 2021). The tax incentive policy contained in the Regulation of the Minister of Finance (PMK) Number 86/PMK.03/2020 on Tax Incentives for Taxpayers Affected by the Covid-19 Pandemic provides several tax incentives, including Income Tax 21 Borne by the Government for workers earning a gross income of no more than IDR 200 million per year, the final Income Tax of MSMEs, exemption of Income Tax 22 Import, reduction of Installment of Income Tax 25 by 30 percent and restitution of Value Added Tax (VAT) accelerated ( Kumala \& Junaidi, 2020).

Any tax subject who meets the criteria as a taxpayer under the provisions of taxation is inseparable from the obligation to pay taxes, report as well as administrating taxation. Because of the importance of tax contributions in state revenues, taxpayers have a large role and responsibility in implementing the provisions of the tax law and its implementation regulations (Hannan et al., 2022). Tax reform that began in 1983 implemented a system of tax administration with a selfassessment system where the system can increase people's participation in the fulfillment of tax obligations that are a vital source of state revenue. Self-assessment system gives taxpayers the authority to calculate, pay, and report their own tax obligations. In the implementation of selfassessment system, Fiscus has a role in providing services, construction and supervision of the fulfillment of tax obligations by taxpayers (

Taxes are one of the main sources of state revenue that can be used in financing Indonesia's national development, namely educating the life of the nation to create the general welfare, protect 


\section{Evaluation of the Utilization of Tax Incentive Policies during the Covid-19 Pandemic in the Framework of National Economic Recovery \\ Kumala and Bakar}

all Indonesian blood, and help carry out world order and lasting peace (Kumala \& Junaidi, 2019). Referring to Law Number 17 of 2003 concerning State Finance, state revenue is all revenues derived not only from taxation, but including state income that is not in the tax category and in the form of grants as state revenues sourced from within and from abroad (Aditya, 2021). The characteristics of taxes include taxes levied based on the strength of the law and the rules of implementation (Pendit et al., 2021). The government enacted Law Number 6 of 1983 about General Tax (Ketentuan Umum Perpajakan/KUP) and continued to be updated until last with law Number 28 of 2007 (Resmi \& Barmawi, 2022). The object of the tax is income, so to regulate specifically regarding income tax the government sets out Law Number 36 of 2008 (UndangUndang Pajak Penghasilan) which since it was issued has first undergone the fourth change as an income tax law (Saniananda, 2020). Since the end of 2019 state revenues decreased when the Covid-19 Pandemic hit the world and affected health, social and economic problems including in Indonesia, in the second quarter of 2020 Indonesia experienced growth of minus $5.32 \%$ compared to the previous year, and is expected to enter into an economic recession in the third quarter of 2020 (Muhyiddin \& Nugroho, 2021).

The government decided to extend the tax incentive policy in the National Economic Recovery Program 2021 (Sarjono, 2021). This policy is contained in PMK Number 9/PMK.03/2021 and is valid until June 30, 2021. This tax incentive policy consists of: (a) government-borne Income Tax 21 waivers; (b) the final Income Tax of MSMEs; (c) The final Income Tax of construction services; (d) exemption from the collection of Income Tax 22 imports; (e) reduction of the installment of Income Tax 25; and (f) Value Added Tax (VAT) incentives. This tax incentive provided by the government aims to encourage people's purchasing power, meet imports of raw materials production for sectors still affected by the Covid-19 pandemic, and to help the company's cash flow to return to business activities. But on the other hand, the extension of these incentives will have implications for the eroding of state revenues (ulawi, 2020).

But in the first half of 2021 tax revenues grew $7.60 \%$ or by IDR 647.70 trillion or $52.68 \%$ against the 2021 state budget target when compared to the same period in 2020. The increase in the realization of this revenue is thanks to the active contribution of taxpayers throughout Indonesia (Padyanoor, 2020). In the state budget scheme, this receipt is then channeled in various forms of financing including assistance in the framework of the Covid-19 pandemic (Saniananda, 2020). One form of distribution of the National Economic Recovery Program which becomes an instrument for handling health and economic recovery. Realization of National Economic Recovery Program in 2021 to July 16, 2021 reached IDR 277.36 trillion from a ceiling of IDR 744.75 trillion (Indahsari \& Fitriandi, 2021).

Therefore, in mid-2021 the Government decided to extend the tax incentive policy again in the National Economic Recovery Program. This policy is contained in PMK Number 82/PMK.03/2021 and valid until December 31, 2021. This tax incentive policy consists of: (a) government-borne Income Tax 21 waivers; (b) the final Income Tax of MSMEs; (c) The final Income Tax of construction services in the program to accelerate the improvement of irrigation water use (P3-TGAI); (d) exemption from the collection of Income Tax 22 imports; (e) reduction of the installment of Income Tax 25; and ( $\mathrm{f}$ ) adjustment of preliminary return incentives of a maximum of IDR 5 billion for VAT. 


\section{Evaluation of the Utilization of Tax Incentive Policies during the Covid-19 Pandemic in the Framework of National Economic Recovery \\ Kumala and Bakar}

Until now, Indonesia still faces Covid-19 and is still in the process of economic recovery. However, the Directorate General of Taxes (DGT) was able to achieve the target of $100 \%$ tax revenue according to the target mandated in the 2021 State Budget even before the close of the year. As of December 26, 2021, DGT has recorded a net amount of tax revenue of IDR 1,231.87 trillion. Thus, tax revenues have met the mandated target in the 2021 State Budget of IDR 1,229.6 trillion and there will even still be an increase until the close on December 31. This achievement is thanks to the contributions of all Taxpayers who continue to be committed to supporting the nation and state by paying taxes.

Director General of Taxes Suryo Utomo reported that a total of 138 Tax Service Offices (KPP) throughout Indonesia managed to achieve the target of tax revenues of more than $100 \%$ of the target set in each office. A total of seven Regional Offices also managed to contribute more than 100\% achievements, namely Regional Offices DGT South Jakarta I, Regional Offices DGT Big Taxpayer, Regional Offices DGT Special of Jakarta, Regional Offices DGT North Sulawesi, Central, Gorontalo, and North Maluku, Regional Offices DGT West Kalimantan, Regional Offices DGT South and Central Kalimantan, and Regional Offices DGT North Jakarta. That is, the achievement of tax revenues that continue to show improvement efforts must be maintained momentum, in order to continue to the 2022 state budget.

One of the focus of the country is adrift of tax policy. Some countries issue various tax relaxation policies to predict the use of tax incentive policies in the wake of the Covid-19 outbreak. Including Indonesia which implements various tax relaxations. From the description, the purpose of this study is to find out and analyze the evaluation of the utilization of tax incentive policies during the Covid-19 pandemic in the framework of national economic recovery.

\section{METHOD}

This research procedure uses qualitative procedures (Creswell, 2017). Qualitative research is a procedure for collecting and analyzing non-quantitative information with the aim of studying social bonds and reality stories felt by informants (Nunfam, 2021). Qualitative research is research that means to understand events about what is felt by the research theme such as attitudes, assumptions, encouragement, actions, and others in a holistic way, and with the method of stories in the form of words and language, in a special condition that is natural and by using various natural ordinances (Sugiyono, 2019).

In this research, researchers sorted using a type of descriptive research, is to make a tower of events whose operationalization revolves around the collection of information, information work and understanding of information that is given meaning in a logical way by always grasping the principles of common sense as a result of creating holistic conclusions. Information can be through literary research, by reading and observing and analyzing various references, both in the form of archives, newsletters, publishing information from the ministry of finance or from legal websites. 
Evaluation of the Utilization of Tax Incentive Policies during the Covid-19 Pandemic in the Framework of National Economic Recovery

Kumala and Bakar

\section{RESULT AND DISCUSSION}

\section{Evaluation of Tax Incentive Performance 2020}

The Ministry of Finance noted that tax revenues in 2020 contracted quite deeply by $19.7 \%$ (yoy). This is as a result of the Covid-19 pandemic as well as the provision of tax incentives that provide significant pressure, where these incentives contributed $22.1 \%$ to the decrease in tax revenues. But tax facilities that aim for business recovery are actually underutilized widely by business actors. The realization of tax incentives until December 2020 was recorded at IDR 55.03 trillion or only $56.7 \%$ of the total budgeted.

Figure 1. Realization of Tax Incentives in the Economic Recovery Program 2020 (IDR trillion)

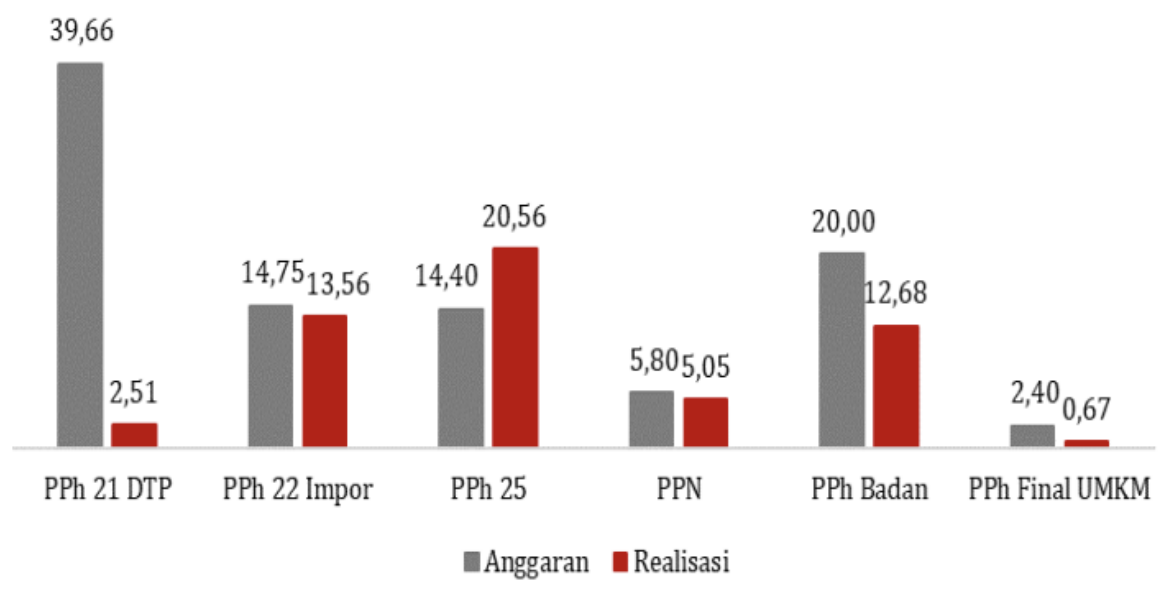

Source: Ministry of Finance, 2022

From figure 1 explains that the lowest incentive realization is the tax incentive Income Tax 21 borne by the government, which is recorded only utilized at $6.3 \%$ of the total budget. Likewise, the final Income Tax of MSMEs which was only realized in 2020 amounted to $28 \%$ or IDR 0.67 trillion. Some of the things that are noted for the low realization of tax incentives in 2020 include, first there is the issue of trust in tax authorities that by utilizing tax incentives can pose risks. As stated by tax observer Centre for Indonesia Taxation Analysis (CITA) that the employee tax incentive scheme only benefits employees, while for companies this scheme is less attractive because it is considered to pose risks. Seeing the tax system is already in the form of reporting, then there is a possibility that taxpayers can be checked for the future. Second, socialization is less effective than the government to the community. Third, the sluggish economic conditions make the utilization of tax incentives does not run optimally because tax incentives are not what businesses need. Businesses are more in need of consumer demand.

\section{Evaluation of Tax Incentive Performance in 2021}

In the midst of an economy that is still beset by uncertainty due to the pandemic in 2021, of course, it will still erode tax revenues. Reflecting from 2020, the amount of tax incentive contribution to the decrease in tax revenue is expected to continue in 2021. In addition, according to the OECD (2020) the provision of tax incentives when pandemics are vulnerable to abuse and not on target. 


\section{Evaluation of the Utilization of Tax Incentive Policies during the Covid-19 Pandemic in the Framework of National Economic Recovery \\ Kumala and Bakar}

This is because policy making is generally done in a short time and the limitations of tax authorities in conducting surveillance in times of pandemic. The OECD pointed out that providing employee tax incentives provides a loophole for some companies to create fictitious data related to the number of employees and the amount of wages given. The mode could potentially escape checks carried out by tax authorities due to lack of supervision due to remote working patterns carried out by tax authorities. In addition to the risk of misuse of incentive facilities, there are risks to data security systems caused by remote working patterns. The policies of a number of countries that enforce work from home make data transmission done remotely using information technology, which allows access by unauthorized parties (Resti Pratiwi \& Liana, 2021)

Taxes are the backbone of the state budget in the handling of pandemics and economic recovery. However, in the midst of economic uncertainty, taxes that should be a source of revenue, are dedicated as incentives to help taxpayers. Therefore, the government helps with incentives, later when the normal economy of the community pays taxes again so that we can use it for development.

In supports national economic recovery programs, fiscal policies such as tax incentives are very helpful to maintain cash flow through government-borne income taxes. The money used to pay taxes is used to become working capital, for everyday and the hope is that it can survive even as things improve later when the economy recovers can pay taxes even more strongly.

On July 1, 2021, the Government has established The Minister of Finance Regulation Number 82/PMK.03/2021 on Changes to The Minister of Finance Regulation Number 9/PMK.03/2021 on Tax Incentives for Taxpayers Affected by the Corona Virus Disease Pandemic 2019. With PMK-82, taxpayers can take advantage of incentives until December 2021.

Tax incentives that have been utilized in the framework of the National Economic Recovery Program have reached IDR 63.16 trillion (100.5\%) from the ceiling of IDR 62.83 trillion. The allocation of the utilization of tax incentives is as follows:

1. Income Tax 21 borne by the government for 87,086 employers.

2. Exemption of Import Income Tax 22 for 9,601 taxpayers.

3. Preliminary Return (Restitution) of VAT for 2,778 taxpayers.

4. VAT borne by the government Property for 942 sellers.

5. Luxury Tax Cars for 6 sellers.

6. Income Tax Final MSMEs borne by the government for 134,922 MSME taxpayers.

7. Reduction in Installment Income Tax 25 for 58,057 taxpayers.

8. Decreased Agency Income Tax Rate for all taxpayers.

9. Domestic VAT Rental Outlet for 885 taxpayers.

10. BM by the government for import value amounted to Rp4.51 trillion.

This achievement is thanks to the contributions of all taxpayers who continue to be committed to supporting the nation and country by paying taxes. The achievement is tax revenue that continues to show improvement efforts must be maintained momentum, in order to continue to the 2022 state budget. The challenge to next year is the Voluntary Disclosure Program on January 1. There is a Harmonization of Taxation Regulation Act (Undang-Undang Harmonisasi Peraturan 


\section{Evaluation of the Utilization of Tax Incentive Policies during the Covid-19 Pandemic in the Framework of National Economic Recovery \\ Kumala and Bakar}

Perpajakan) with all including April 1 Value Added Tax (VAT) being 11\%, and there is economic recovery through continuously strengthened monitoring. It is expected that the economic recovery will secure the 2022 state budget which is the final limit of the deficit above $3 \%$ as law Number 2 of 2020 .

\section{CONCLUSION}

The implementation of tax incentive policies during the Covid-19 pandemic in the framework of National Economic Recovery is very effective because it has reached 100.5\% or IDR 63.16 trillion from the ceiling of IDR 62.83 trillion. The allocation of tax incentive utilization is obtained from (1) Income Tax 21 borne by the government for 87,086 employers. (2) Exemption of Import Income Tax 22 for 9,601 taxpayers. (3) Preliminary Return (Restitution) of VAT for 2,778 taxpayers. (4) VAT borne by the government Property for 942 sellers. (5) Luxury Tax Cars for 6 sellers. (6) Income Tax Final MSMEs borne by the government for 134,922 MSMEs taxpayers. (7) Reduction of Installment Income Tax 25 for 58,057 taxpayers. (8) Decrease in The Agency Income Tax Rate for all taxpayers. (9) Domestic VAT Rental Outlet for 885 taxpayers. (10) BM by the government for import value of IDR 4.51 trillion. This achievement is thanks to the contributions of all Taxpayers who continue to be committed to supporting the nation and the country by paying taxes that continue to show improvement efforts must be maintained momentum, in order to continue to the 2022 state budget.

\section{REFERENCE}

Aditya, G. N. I. A. (2021). Perhitungan Kebijakan Insentif Pajak Penghasilan di Masa Pandemi Covid-19. Eqien: Jurnal Ekonomi Dan Bisnis, 8(2), 155-162. https://doi.org/10.34308/eqien.v8i2.247

Anderson, R. M., Heesterbeek, H., Klinkenberg, D., \& Hollingsworth, T. D. (2020). How will countrybased mitigation measures influence the course of the COVID-19 epidemic? The Lancet, 395(10228), 931-934. https://doi.org/10.1016/S0140-6736(20)30567-5

Andrew, R., \& Sari, D. P. (2021). Insentif PMK 86/2020 Di Tengah Pandemi Covid 19: Apakah Mempengaruhi Kepatuhan Wajib Pajak UMKM Di Surabaya? Jurnal Akuntansi Dan Pajak, 21(02). https://doi.org/10.29040/jap.v21i02.1597

Aulawi, A. (2020). Penerbitan Peraturan Pemerintah Pengganti Undang-Undang Nomor 1 Tahun 2020 Sebagai Strategi Kebijakan Pajak Pemerintah Indonesia Dalam Menghadapi Dampak Pandemi Covid-19 Terhadap Keuangan Negara. Progress: Jurnal Pendidikan, Akuntansi Dan Kenangan, 3(2), 110 132. https://doi.org/10.47080/progress.v3i2.936

Baldwin, R., \& Tomiura, E. (2020). Thinking ahead about the trade impact of COVID-19. In Economics in the Time of COVID-19 (1st ed., Vol. 1, pp. 59-71). Centre for Economic Policy Research. https://repository.graduateinstitute.ch/record/298220?ln=en

Barbier, E. B., \& Burgess, J. C. (2020). Sustainability and development after COVID-19. World Development, 135, 105082. https://doi.org/10.1016/j.worlddev.2020.105082

Creswell, J. W. (2017). Research Design Pendekatan Kualitatif, Kuantitatif, dan Mixed (S. Z. Qudsy (ed.); 3rd ed.). Pustaka Pelajar. https://opac.perpusnas.go.id/DetailOpac.aspx?id=1213690

Fadhal, S. (2020). Komunikasi Publik di Tengah Krisis: Tinjauan Komunikasi Pemerintah Dalam Tanggap Darurat Pandemi Covid-19. In Media, Komunikasi dan Informasi di Masa Pandemi Covid-19 (1 st ed., pp. 


\section{Evaluation of the Utilization of Tax Incentive Policies during the Covid-19 Pandemic in the Framework of National Economic Recovery}

Kumala and Bakar

1-25). M Bridge Press. https://eprints.uai.ac.id/1469/

Gourinchas, P.-O. (2020). Flattening The Pandemic And Recession Curves. In R. Baldwin \& B. W. di Mauro (Eds.), Mitigating the COVID Economic Crisis: Act Fast and Do Whatever (1st ed., pp. 31-39). CEPR Press. https://voxeu.org/article/flattening-pandemic-and-recession-curves

Hannan, S. A., Honjo, K., \& Raissi, M. (2022). Mexico needs a fiscal twist: Response to Covid-19 and beyond. International Economics, 169, 175-190. https://doi.org/10.1016/j.inteco.2022.01.004

Hasanah, N., \& Indriani, S. (2013). Efektifitas Pelaksanaan Self Assessment System dan Modernisasi Administrasi Pajak Terhadap Kualitas Pelayanan Pajak (Studi Kasus Pada KPP Kebon Jeruk 1). Jurnal Ilmiah Wahana Akuntansi, 8(1), 17-35. http://journal.unj.ac.id/unj/index.php/wahanaakuntansi/article/view/651

Indahsari, D. N., \& Fitriandi, P. (2021). Pengaruh Kebijakan Insentif Pajak di Masa Pandemi Covid-19 Terhadap Penerimaan PPN. Jurnal Pajak Dan Kenangan Negara (PKN), 3(1), 24-36. https://doi.org/10.31092/jpkn.v3i1.1202

Kumala, R., \& Junaidi, A. (2019). Pengaruh Kesadaran Membayar Pajak, Pengetahuan Dan Pemahaman Peraturan Perpajakan Dan Kualitas Layanan Terhadap Kemauan Membayar Pajak Wajib Pajak Orang Pribadi. Jurnal Eksekutif, 16(2), 256-278.

https://jurnal.ibmt.ac.id/index.php/jeksekutif/article/view/235

Kumala, R., \& Junaidi, A. (2020). Strategi Bisnis Dan Pemanfaatan Kebijakan Pajak Di Masa Pandemi COVID-19 Dan Era New Normal (Studi Kasus Pelaku UKM Marketplace). Prosiding Seminar STLAMI, 7(2), 98-103. https://ojs.stiami.ac.id/index.php/PS/article/view/960

Kurniawan, M. B. (2021). Politik Hukum Pemerintah dalam Penanganan Pandemi Covid-19 Ditinjau dari Perspektif Hak Asasi atas Kesehatan. Jumal HAM, 12(1), 37. https://doi.org/10.30641/ham.2021.12.37-56

Malahayati, M., Masui, T., \& Anggraeni, L. (2021). An assessment of the short-term impact of COVID-19 on economics and the environment: A case study of Indonesia. EconomiA. https://doi.org/10.1016/j.econ.2021.12.003

Muhyiddin, M., \& Nugroho, H. (2020). Covid-19, New Normal, dan Perencanaan Pembangunan di Indonesia. Jurnal Perencanaan Pembangunan: The Indonesian Journal of Development Planning, 4(2), 240-252. https://doi.org/10.36574/jpp.v4i2.118

Muhyiddin, M., \& Nugroho, H. (2021). A Year of Covid-19: A Long Road to Recovery and Acceleration of Indonesia's Development. Jurnal Perencanaan Pembangunan: The Indonesian Journal of Development Planning, 5(1), 1-19. https://doi.org/10.36574/jpp.v5i1.181

Nunfam, V. F. (2021). Mixed methods study into social impacts of work-related heat stress on Ghanaian mining workers: A pragmatic research approach. Heliyon, 7(5), e06918. https://doi.org/10.1016/j.heliyon.2021.e06918

Padyanoor, A. (2020). Kebijakan Pajak Indonesia Menanggapi Krisis COVID-19: Manfaat bagi Wajib Pajak. E-Jurnal Akuntansi, 30(9), 2216. https://doi.org/10.24843/EJA.2020.v30.i09.p04

Pendit, I. P. W. L., Budiartha, I. N. P., \& Widiati, I. A. P. (2021). Kebijakan Pemerintah dalam Memberikan Insentif Pajak Penghasilan Pasal 21 Kepada Wajib Pajak Terdampak Pandemi Covid19. Jurnal Konstruksi Hukum, 2(2), 418-423. https://doi.org/10.22225/jkh.2.2.3266.418-423

Resmi, S., \& Barmawi, M. M. (2022). Pemanfaatan Insentif Pajak Untuk UMKM di Masa Pandemi Covid 19. Jurnal Berdaya Mandiri, 4(1), 1-11. https://doi.org/https://doi.org/10.31316/jbm.v4i1.1852

Resti Pratiwi, D., \& Liana, D. (2021). Insentif Pajak Dalam Program PEN: Implementasi \& Tantangan 
Evaluation of the Utilization of Tax Incentive Policies during the Covid-19 Pandemic in the Framework of National Economic Recovery

Kumala and Bakar

Perpanjangannya Tahun 2021. Pusat Kajian Anggaran Badan Keablian DPR RI, 01(1), 1-4. https://berkas.dpr.go.id/puskajianggaran/bib/public-file/bib-public-3.pdf

Saniananda, M. Q. D. (2020). Analisis Efektivitas Pemberian Insentif Pajak Untuk Pajak Penghasilan Pasal 25 di Masa Pandemi Covid-19 dalam PMK no. 110/PMK.03/2020 Terhadap Kepatuhan Wajib Pajak di Kota Malang. Jurnal Ilmiah Mahasiswa Fakultas Ekonomi Bisnis Universitas Brawijaya, 9(2), 1-29. https://jimfeb.ub.ac.id/index.php/jimfeb/article/view/7467

Sariwati, R. (2021). Kajian Yuridis Pemberian Insentif Pajak Penghasilan Pada Masa Pandemi Covid-19. Jurnal Cakrawala Hukum, 12(1). https://doi.org/10.26905/idjch.v12i1.5722

Sarjono, B. (2021). Dampak Insentif PPH Pasal 21 Saat Pandemi Covid-19 Terhadap Take Home Pay dan Pelaporan SPT Tahunan. Jurnal Bisnis Terapan, 5(2), 257-270.

https://doi.org/10.24123/jbt.v5i2.4531

Sparrow, R., Dartanto, T., \& Hartwig, R. (2020). Indonesia Under the New Normal: Challenges and the Way Ahead. Bulletin of Indonesian Economic Studies, 56(3), 269-299. https://doi.org/10.1080/00074918.2020.1854079

Sugiyono. (2019). Metode Penelitian Kuantitatif Kualitatif dan R\&D (I). Alfabeta. https://cvalfabeta.com/product/metode-penelitian-kuantitatif-kualitatif-dan-rd-mpkk/

Wang, C., Wang, Z., Wang, G., Lau, J. Y.-N., Zhang, K., \& Li, W. (2021). COVID-19 in early 2021: current status and looking forward. Signal Transduction and Targeted Therapy, 6(1), 114. https://doi.org/10.1038/s41392-021-00527-1

Wantasen, M. A., Sondakh, J. J., \& Suwetja, I. G. (2021). Analisis Penerimaan Pajak Sebelum dan Sesudah Adanya Insentif Pajak Bagi Wajib Pajak yang Terdampak Covid-19 Selama Masa Pandemi Pada KPP Pratama Manado. Going Concern : Jurnal Riset Akuntansi, 16(4), 387-397. https://doi.org/https://doi.org/10.32400/gc.16.4.37587.2021

Wiryawan, I. W. (2020). Kebijakan Pemerintah Dalam Penanganan Pandemi Virus Corona Disease 2019 (Covid-19) di Indonesia. Percepatan Penanganan COVID-19 Berbasis Adat Di Indonesia, 179-188. https://e-journal.unmas.ac.id/index.php/webinaradat/article/view/1180 